KESMAS, Vol.9, No.2, September 2015, pp. $85 \sim 94$

ISSN: $1978-0575$

\title{
SYSTEMATIC REVIEW: OCCUPATIONAL STRESS AND RELATED FACTORS AMONG HOSPITAL NURSES
}

\author{
Ridha Restila \\ Public Health Faculty of Indonesia University \\ Email: ridharestila.ui.ac.id
}

\begin{abstract}
Background: Stress is one of the factors that affect the performance of nurses. According to Nursing Times 2014, more than 60\% of nurses say they have experienced effects of workrelated stress, such as physical or mental health problem. This systematic review research aimed at exploring factors related to occupational stress among hospital nurses involved 16 research.

Method: This research consist of 8 research from Indonesia in the year 2000-2013 and another 8 research obtained from international journals in the year 2010-2015. The entire research using cross sectional study design, sample size ranged from 24 - 2613.

Results: There are differences in the average number of research samples in the Indonesian research and international research (pvalue $=0,004$ ). Total number of variables studied were 70 independent variables. The number of variables studied ranged from 4-25 per study. The most studied variables were marital status, salary, age, education, job demands, length of employment, shift work, promotion, and gender. From 9 variables most studied, promotion variable has a significant percentage of the highest $p$ value, while the gender variable has no significant. Reference number used ranged from 7-59 references. No difference reference amount between Indonesian research and international research ( $p$ value $=0.806$ ).

Conclusion: From the results of this study can be seen at least 9 variables most studied of the stress on the nurses.
\end{abstract}

Keywords: occupational stress, job stress, nurses, hospital

\section{Introduction}

Stress at work is one of the factors that can cause a decline in performance on almost all types of jobs.Although all work may be potentially stressful, certain types of work are recognised as being more likely to induce stress. This is particularly happen in service industry like such as police force, the ambulance service, and health care. ${ }^{1}$ Nurses, as a part of health care, may exposed to frequent deadlines, high pressure and no room for error.

Nurses are the most frequent medical staff interact with patients. Therefore, the nurses must have the physical and mental events healthy in order to maintain the quality of health services. Stress is one of the factors that affect the performance of nurses. $^{2}$

A continual or recurrent state of stress can eventually lead to anxiety states and depression. Stress has also been shown to be associated with disease such as cancer and coronary heart disease. Not all mental ill health arises from a gradual deterioration of mental well being. Although there is disagreement about the influence of the encironment on the development of some forms of mental illness, such as depression and schizophrenia, in many individuals these illness seem to arise without reference to the general psychosocial environment. ${ }^{1}$

Patient safety has now become a central theme for quality control within the health care system. Study from Stord/Haugesund University College found that nurses assessed that work-related stress is a risk factor when evaluating patient safety. They

Systematic Review: Occupational Stress and Related Factors Among .... (Ridha Restila) 
shown that stress in the work place is a problem for nurses, especially for those working with critically ill patients. ${ }^{3}$ According to Nursing Times 2014 , more than $60 \%$ of nurses say they have experienced effects of work-related stress, such as physical or mental health problem. ${ }^{4}$

Systematic review research aimed at exploring factors related to occupational stress among hospital nurses involved 16 studies. This research consist of 8 studies from Indonesia in the year 2000-2013 and another 8 studies obtained from international journals in the year 2010-2015. From this study we can find what factors are most studied and obtained significant results that can be the basis of hospital management. Moreover, it can also give an idea of what variables are associated with occupational among hospital nurses in future studies.

\section{Research Method}

Systematic review is a powerful research tool which aims to identify and synthesize all evidence relevant to a research question. Systematic reviews aim to include all literature that is relevant to the review question, no matter the direction or significance of the result, thus reducing bias and improving our confidence in the conclusions. Individual studies contributing to a systematic review are called primary studies; a systematic review is a form a secondary study., $\mathrm{A}$ well-conducted systematic reviews provide decisionmakers with synthesized, reliable information which can then be used in policy-making. ${ }^{5,7}$

Before analize data, we have to make inclusion criteria; they are a critical part of the review. Deciding on and laying out the criteria clearly before the review commences will ensure the correct papers are selected to answer the review question, and will save time later on. Factors you may want to consider are: the sample/population of interest; the independent variable; outcomes; study design and setting; language; and publication type. ${ }^{5}$

Research is a systematic review. Data collection is held in two stages, the data research in Indonesia and International research data. This source of research data obtained through the Internet and public health library, University of Indonesia. Criteria for the research is the study of occupational stress among nurses in hospitals and analytic study.

From the results of the literature search via the Internet, we found 2 study of occupational stress on hospital nurses. Based on the abstract, results, and conclusions, only one literature that appropriate with the criteria. Research from the University of Indonesia libraries accessed through http://lib.fkm.ui.ac.id/opac/id/ with the keyword "stres perawat". Only 7 research from 16 result that approriate with criteria.

International Journal relating to occupational stress in nurses obtained via EBSCOhost Research Databases include Academic Search Complete, CINAHL Plus With Full Text, and MEDLINE With Full Text. Key words used were occupational stress, nurses, and hospital. The obtained results of keyword 782 journals. Then we restricted only for full text journals and we obtained 442 journals. Then restricted to 442 full text journals and obtained. Span of research publications starting in 2010 - 2015, english language, Full PDF journal, then we found 213 journals. The journals were selected based on title and abstract in order to obtain the final result 8 journals. 


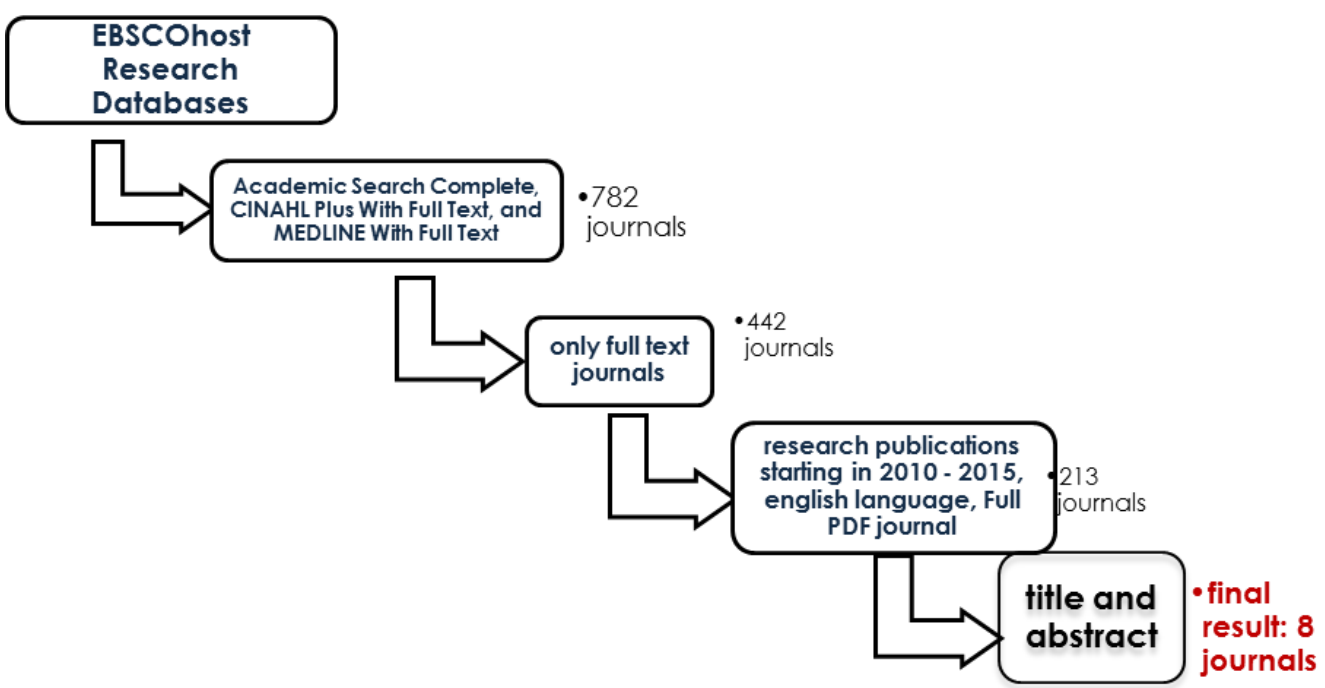

We list all research in table then the data were analized with univariate and bivariate analysis. Univariate analysis forsee average values, minimum and maximum values, and frequency distribution. Bivariate analysis to see the difference between Indonesian studies and International studies. We used SPSS to see difference using $t$ - test and non parametrik test. ${ }^{8,9}$

Then the whole research that qualify would be elaborated through the master table describing briefly the findings of each study. It could be seen from the table of variables that had been studied related to the stress that occurs in nursing. As well as the variables which are most often related / significant to stress.

\section{Results and Analysis}

\section{A. Results}

There are 16 research that will be synthesized. All research using cross sectional study design. The number of samples per study ranged from 24 samples up to 2613 samples. The average number of samples for research in Indonesia is 65.13 and the international research is 785.63. Based on the distribution of data, we used non-parametric statistical test(8). Statistical analysis showed $p$ value of 0.004 , then there is a statistically significant difference in the number of samples between Indonesian research and international research.

Table 1. Sample Size difference

\begin{tabular}{cccccc}
\hline No & Research & Mean & Min & Max & P Value \\
\hline 1 & Indonesian Research & 65,13 & 24 & 100 & 0,004 \\
2 & Internasional Research & 785,63 & 87 & 2613 & \\
\hline
\end{tabular}

Reference number used has a minimum value of 7 and a maximum of 59 . Average references used in Indonesia is 32,13 references and international research is 33.88.Statistical analysis showed Pvalue 0,806 then there was no statistically significant difference in the number of references used between Indonesian research and international research.

Table 2. References research difference

\begin{tabular}{cccccc}
\hline No & Research & Mean & Min & Max & P Value \\
\hline 1 & Indonesian Research & 32,13 & 7 & 59 & 0,806 \\
2 & Internasional Research & 33,88 & 14 & 57 & \\
\hline
\end{tabular}


Table 3 illustrates the 16 research related to job stress in nurses. Research from 1 to 8 are Indonesian research conducted in $2004-2014$. While the study 9 to 16 are international studies conducted in various countries in 20102014.

Tabel 3. Research Description

\begin{tabular}{|c|c|c|c|c|c|}
\hline Author & Title & Year & $\begin{array}{l}\text { Sample } \\
\text { Size }\end{array}$ & $\begin{array}{c}\text { Total } \\
\text { Variable }\end{array}$ & Reference \\
\hline Aji Utomo & $\begin{array}{l}\text { Gambaran Kejadian Stres Kerja } \\
\text { Berdasarkan Kakteristik Pekerjaan pada } \\
\text { Perawat Intensive Care Unit dan Unit } \\
\text { Gawat Darurat di Rumah Sakit Mitra } \\
\text { Keluarga Bekasi Tahun } 2004\end{array}$ & 2004 & 24 & 4 & 24 \\
\hline $\begin{array}{l}\text { Indah } \\
\text { Permata Sari }\end{array}$ & $\begin{array}{l}\text { Faktor - Faktor yang Berhubungan } \\
\text { dengan Stres Kerja pada Perawat RS } \\
\text { Jiwa DR Soeharto Heerdjan Tahun } 2013\end{array}$ & 2013 & 100 & 9 & 42 \\
\hline $\begin{array}{l}\text { Bangun Setia } \\
\text { Putra }\end{array}$ & $\begin{array}{l}\text { Analisis Faktor - Faktor Penyebab Stress } \\
\text { Kerja Pada Perawat Pelaksana RS } \\
\text { Tubulbu Cimanggis Tahun } 2013\end{array}$ & 2013 & 99 & 12 & 28 \\
\hline Evy Early & $\begin{array}{l}\text { Faktor - Faktor yang Menimbulkan Stress } \\
\text { Kerja pada Perawat Pelaksana di Ruang } \\
\text { Rawat Inap RS Husada Jakarta }\end{array}$ & 2003 & 100 & 6 & 32 \\
\hline $\begin{array}{l}\text { Margaretha } \\
\text { Lelyana }\end{array}$ & $\begin{array}{l}\text { Faktor - Faktor yang Berhubungan } \\
\text { dengan Stres Kerja pada Perawat di RS } \\
\text { PELNI 'Petamburan' Jakarta } 2004\end{array}$ & 2004 & 50 & 6 & 38 \\
\hline $\begin{array}{l}\text { Machdalena } \\
\text { Simanjuntak }\end{array}$ & $\begin{array}{l}\text { Faktor Risiko Stres Kerja pada Perawat } \\
\text { Ruang Rawat Inap di RS Pantai Indah } \\
\text { Kapuk Jakarta }\end{array}$ & 2013 & 63 & 13 & 27 \\
\hline $\begin{array}{l}\text { Dewandra } \\
\text { Gautama }\end{array}$ & Studi Stres Kerja Perawat di RS X & 2008 & 45 & 15 & 59 \\
\hline Ryo S. Gobel & $\begin{array}{l}\text { Faktor - Faktor yang Berhubungan } \\
\text { dengan Stress Kerja pada Perawat di } \\
\text { Ruang ICU dan UGD RS Datoe } \\
\text { Binangkang Kabupaten Bolaang } \\
\text { Mongondow }\end{array}$ & 2014 & 40 & 5 & 7 \\
\hline $\begin{array}{l}\text { G. Mark and } \\
\text { A.P Smith }\end{array}$ & $\begin{array}{l}\text { Occupational stress, job characteristics, } \\
\text { coping, and the mental health of nurses }\end{array}$ & 2011 & 870 & 12 & 36 \\
\hline $\begin{array}{l}\text { Nirmanmoh } \\
\text { Bhatia }\end{array}$ & $\begin{array}{l}\text { Occupational Stress Amongst Nurses } \\
\text { from Two Tertiary Care Hospitals in Delhi }\end{array}$ & 2010 & 87 & 5 & 22 \\
\hline Yu Qin Gao & $\begin{array}{l}\text { Anxiety symptoms among Chinese } \\
\text { nurses and the associated factors: a } \\
\text { cross sectional study }\end{array}$ & 2012 & 1437 & 25 & 57 \\
\hline Hui Wu & $\begin{array}{l}\text { Occupational Stress Among Hospital } \\
\text { Nurses : Cross Sectional Survey }\end{array}$ & 2010 & 2613 & 10 & 38 \\
\hline $\begin{array}{l}\text { Mohsen } \\
\text { Karchani }\end{array}$ & $\begin{array}{l}\text { Job Stress and related factors in Nurses } \\
\text { in Ilam }\end{array}$ & 2012 & 100 & 9 & 14 \\
\hline $\begin{array}{l}\text { Huda M. } \\
\text { Al-Makhaita }\end{array}$ & $\begin{array}{l}\text { Predictors of work-related stress among } \\
\text { nurses working in primary and secondary } \\
\text { health care levels in Dammam, Eastern } \\
\text { Saudi Arabia }\end{array}$ & 2014 & 637 & 7 & 29 \\
\hline $\begin{array}{l}\text { Sharma } \\
\text { Parul }\end{array}$ & $\begin{array}{l}\text { Occupational stress among staff nurses: } \\
\text { Controlling the risk to health }\end{array}$ & 2014 & 100 & 14 & 35 \\
\hline $\begin{array}{l}\text { Saunjoo L. } \\
\text { Yoon }\end{array}$ & $\begin{array}{l}\text { Job-Related Stress, Emotional Labor, } \\
\text { and Depressive Symptoms Among } \\
\text { Korean Nurses }\end{array}$ & 2013 & 441 & 11 & 40 \\
\hline
\end{tabular}

Many factors can cause stress on nurses. From the 16 studies, we found 70 independent variabels as risk factor that affact stress on nurses. Total independent variables studied of 16 studies was 163 . From 163 variables, there 
are same independent variables in each study, so the end result was found 70 different kinds of independent variables. These variables are
1. Job Demands
23. Motivation
24. Overtime Work
49. Life Events
2. Underload
25. Turn Over
50. Alcohol
3. Promotion
26. Nurse - Doctor
51. Meals
4. Salary
5. Hazard Relationship
6. Shift Work
27. Lie Demands
7. Work Routine
28. Physical Hazard
8. Role In Organization
29. Chemical Hazard
9. Interpersonal Relationship
30. Biological Hazard
31. Ergonomic Hazard
52. Physical Excercise
53. Hospital Grade
54. Job Position
55. Night Shift
56. Intension Of Leaving
10. Climate And Organization Structure
11. Gender
12. Age
13. Education
14. Marital Status
15. Coworker Relationship
32. Management performance
33. Work Training
34. Work Equipment
35. Job Satisfaction
36. Social Support
37. Skill Disrection
38. Intrinsic Reward
39. Extrinsic Effort
40. Over Commitment
57. Decision Latitude
58. Effort/Reward Ratio
16. Relationship with Supervisor
17. Nurse - Patient Relationship
41. Problem Focus Coping
42. Seek Advice
43. Self Blame
18. Family Support
19. Decision Authority
20. Supervisor Support
21. Length Of Employment
44. Wishful Thinking
45. Avoidanc
46. Type Of Hospital
47. Vacation
22. Work Time
48. Chronic Disease
59. Conflict With Physician
60. Nationality
61. Number Or Children
62. Departements
63. Attitude Of Doctor
64. Attitude Of Nurse
65. Attitude Of Para- Medical
66. Attitude Of Patient Attendant
67. Enough Time To Rest
68. Job Tiring
69. Enough Holiday
70. Employment Status

From all independent variables above, 7 varibles will be explained. These variables is the most studied variables from 16 research. They are Job Demands, Promotion, Shift Work, Gender, Age, Education, Marital Status, Salary, and Length Of Employment or duration of employment.

Table 4. Factors Related to Occupational Stress Among Hospital Nurses

\begin{tabular}{|c|c|c|c|c|c|c|c|c|c|c|c|c|c|c|c|c|c|c|}
\hline No & $\begin{array}{l}\text { Independent } \\
\text { Variable }\end{array}$ & S1 & $\mathrm{S} 2$ & S3 & S4 & S5 & S6 & S7 & S8 & S9 & $\mathrm{S} 10$ & S11 & $\mathrm{S} 12$ & $\mathrm{~S} 13$ & S14 & S15 & S16 & Total \\
\hline 1 & $\begin{array}{l}\text { Marital } \\
\text { Status }\end{array}$ & & & 1 & 1 & 1 & & 1 & & & 1 & 1 & 1 & 1 & 1 & 1 & 1 & 11 \\
\hline 2 & Salary & 1 & 1 & & & 1 & 1 & & & & & 1 & 1 & 1 & & 1 & 1 & 9 \\
\hline 3 & Age & & & 1 & & & & & 1 & & 1 & 1 & 1 & & 1 & 1 & 1 & 8 \\
\hline 4 & Education & & & 1 & 1 & & & & 1 & & & 1 & 1 & 1 & 1 & & 1 & 8 \\
\hline 5 & $\begin{array}{c}\text { Job } \\
\text { Demands }\end{array}$ & 1 & 1 & 1 & & 1 & 1 & & & 1 & & 1 & & & & & & 7 \\
\hline 6 & $\begin{array}{l}\text { Length Of } \\
\text { Employment }\end{array}$ & & & & 1 & & & 1 & 1 & & 1 & 1 & & 1 & & & 1 & 7 \\
\hline 7 & Shift Work & & 1 & 1 & & & 1 & 1 & & & & & & & 1 & & 1 & 6 \\
\hline 8 & Promotion & 1 & 1 & & & 1 & 1 & 1 & & & & & & & & & & 5 \\
\hline 9 & Gender & & & 1 & & & & 1 & 1 & & & & & 1 & & 1 & & 5 \\
\hline
\end{tabular}


From the table above, it can be seen that marital status is a variable that is most widely researched, but from the 11 studies, only 2 significant. The most significant variable is the job demands (4 of 7 ) and salary (4 of 9). But according to percentage, variable promotion has the greatest percentage $(50 \%$ or 3 of 5$)$.

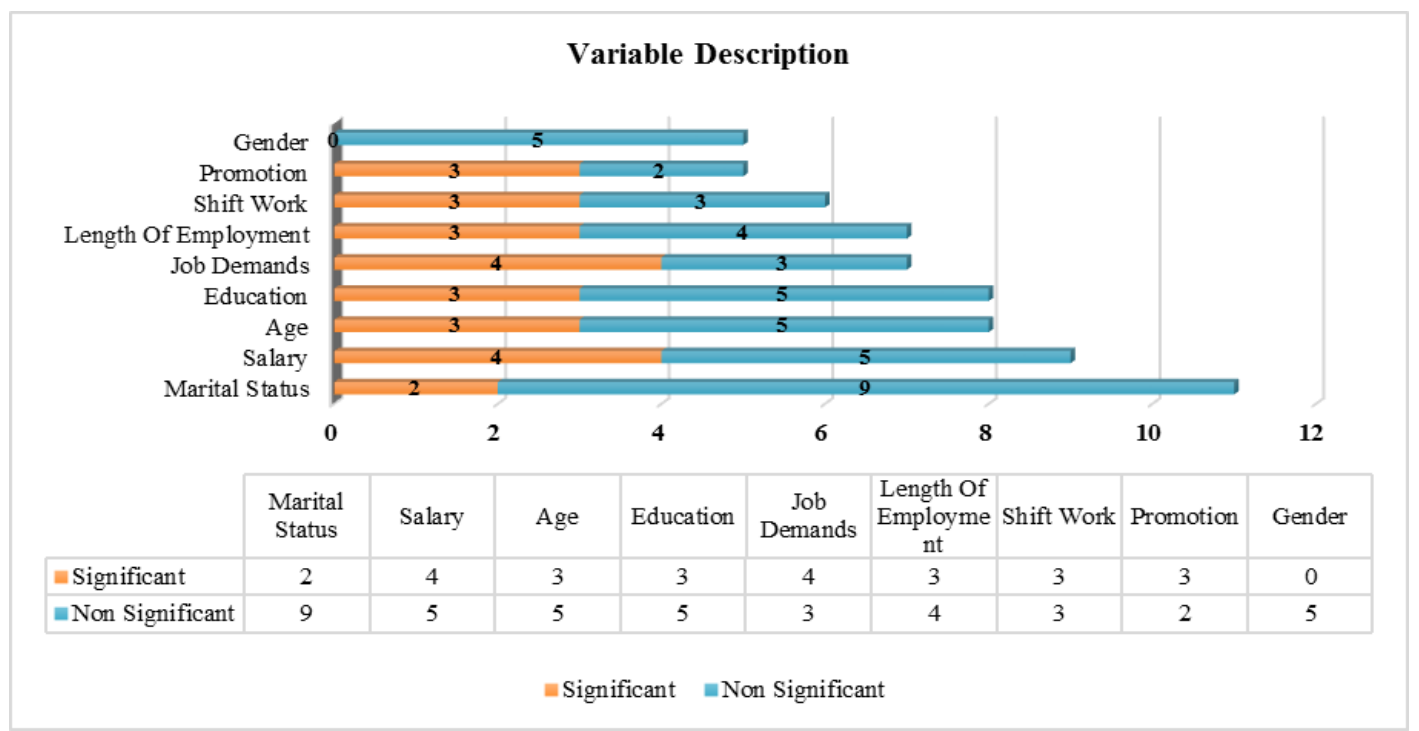

\section{B. Analysis}

\section{a. Marital Status}

People doesnt succeed by oneself in obtaining effective support. They also need others to provide the support for them. Married couples provide support when one of them is confronted by a stressful job problem. ${ }^{10}$ Marital status is related to occupational stress among hospital nurses. ${ }^{11,12}$ According to research, stress found more on nurses who are still single. Marriage affords greater emotional and social support, it offers protection from psychological distress. ${ }^{12}$ However, other studies found that marital status has no relationship with occupational stress in hospital nurses. ${ }^{13-21}$ Stress even more common in the group who had been married. This could suggest that the additional responsibility of married life may adversely increase the stress levels. ${ }^{17}$ So, marital status may be a determinant factor, but it can also be a deterrent factor of stress on nurses, it depend on how the couple maintain their marriage life.

\section{b. Salary}

Inadequate salary is also one of the key factors causing stress. If a high effort is not rewarded (in terms of salary, praise, tenure and/or promotion), stress is likely to be excessive..$^{22}$ Salary is related to occupational stress among hospital nurses. ${ }^{12,18,21,23}$ But other studies found different result. ${ }^{15,19,20,24,25}$ This can be explained because the majority of research on salary only ask respondents monthly salary. Salary relate to the adequacy of one's needs. So it is probable bias may occur. With the same amount of salary, will differ adequacy between one another nurse. This could be influenced to other factors such as marital status, number of children, lifestyle, and other. So when we analyze salary, other factors need to be adjusted. 
c. Age

Age factor is a variable that often arises in the study (8 of 16). This relates to socio-demographic (such as age, sex, education, etc) where the majority of research respondents will ask it.Research shows that age affects the working stress on nurses.12,19,21 Occupational stress found more on young nurses (under 30). This is because the young nurse was new to the work environment, the difference in knowledge obtained during the period of education with the reality lead to occupational stress.

\section{d. Education}

Education is one of socioeconoimic factors that related to occupational stress. People with a lower educational level experience a higher amount of stressful work. ${ }^{26}$ Education is a factor that is found both on the Indonesian research and international research. A total of 3 study says education related to occupational stress in nurses. ${ }^{11,18,19}$ But other five studies have different results. ${ }^{2-14,20,27}$

\section{e. Job Demands}

One of the common causes of occupational stress is high job demands or overload. Too much to do in too little time or work which qualitatively beyond the individual's capacity. It is common for an employee to perceive that he is overload but be unable to find any solution, or at least any solution not perceived as making him vulnerable to management censure. ${ }^{1}$ Research shows job demands associated with occupational stress in nurses. ${ }^{13,15,24,25}$ From 16 research, 7 research examines the job demands, and 3 of them obtain significant results.

\section{f. Length of Employment}

There are 7studies that examined the length of employment, only 3 research that obtain significant results. Stress generally occur in the first year of work. ${ }^{28}$ The longer the length of employment, the percentage of nurses stress will decrease. ${ }^{12,20}$ Just as with other types of work, the nurse who just started working at the hospital will require adaptations to the work environment. During this adaptation process, enabling arise various problems faced by nurses. This kind of situation can cause stress on nurses. However, the longer working at the hospital, they will be more able to adapt to the work environment and be able to resolve the problems faced better.

\section{g. Shift Work}

Shift work is a common occupational stressor and is known to affect neuropsychological rythms such as body temperature, metabolic rate, blood sugar levels, mental eficiency, work motivation, and may ultimately result in stress-related disease. ${ }^{29}$ From 6 research on shift work, 3 of them obtain significant results. ${ }^{11,13,23}$ Most of the nurses at the hospital have shift work morning, noon, and night so the risk is very difficult to avoid.

\section{h. Promotion}

Career planning and development are defined as an important and necessary tool in the development of nurses as professionals and in retaining nurses in a facility (30). Promotion is one of the rewards given to employees on performance that showed. The absence of promotion given supervisor will reduce job motivation and even can cause stress. Promotion variables found 
only in research studies in Indonesia. From 5 studies, 3 of them obtain significant results. ${ }^{15,16,23}$

\section{i. Gender}

Gender is also a demographic factor that is generally asked of each study. There are 5 research that examines gender and found no significant result.gender is not related to stress among hospital nurses. ${ }^{13,16,20,21,27}$ It may caused by two things. First, gender is not related to occupational stress among hospital nurses. Second, the majority of nurses are females. The number of male nurses that involved in the studied are no sufficient to representative of the population. However descriptively, female nurses experienced more occupational stress than male nurses. ${ }^{13,20,21}$

\section{Conclusion}

This study has several limitations. First, the difficulty of finding studies from Indonesia due to lack of publicity. Most studies found only provide abstracts so that the information obtained is very slight. Second, international research on occupational stress in nurses is very much. Therefore we limit the year of publication of the journal in order to obtain recent results.

There are differences and similarities between the Indonesian research with international research. All research use cross sectional study design and there is no difference in average reference between Indonesian research and International research significantly. Most studies also analyzed demographic variables (age, sex Jennis, education, and marital status). The difference between Indonesian research and Internasional research can be seen from the number of sample size used. Indonesian research has fewer sample size than International research. This is because the Indonesian research looked only at one particular hospital. While international research has a wider sample population.

Systematic review analysis results obtained 70 independent variables were examined to determine the factors associated with occupational stress among hospital nurses. The most studied variables are Job Demands, Promotion, Shift Work, Gender, Age, Education, Marital Status, Salary, and Length Of Employment. Patient safety has now become a central theme for quality control within the health care system. Study from Stord/Haugesund University College found that nurses assessed that work-related stress is a risk factor when evaluating patient safety (3). Therefore, Results of this research is expected to provide decision makers with synthesized and reliable information that can be used in policy-making.

Many variables had been investigated to determine the factors causing stress in nurses. Job Demands, Promotion, Shift Work, Gender, Age, Education, Marital Status, Salary, and Length Of Employment were the most widely studied variable. Therefor, further research may consider other variables besides the aforementioned variables. So that we can see if the variables are also a factor contributing to stress in nurses.

Some researches had only distributed a questionnaire to nurses and wait for them to return the questionnaires so it can not be determined whether the nurse is a selected sample or not. Therefore, in future research need to be consideration of the appropriate sample design and sample calculation using the formula according to the study design for the results obtained more representative of the actual population

The significant difference seen in the number of samples between Indonesian research with International research. This is due to research in Indonesia only focused on one hospital alone. Research with larger study populations for example to nurses in the province of $\mathrm{X}$ can be done and likely to give different results.

KESMAS Vol. 9, No. 2, September 2015: $85-94$ 
From the results of this study can be seen at least 9 variables most studied of the stress on the nurses. And has described the variables significant and insignificant. so it can be input to the management of the hospital organization to determine the cause of the problem of occupational stress on the nurses so that the obtained solution right on target.

\section{References}

1. Fingret A., Occupational Health, Great Britain, Routledge, 1995.

2. Gustian Y., Hubungan Stress Kerja Dengan Kinerja Perawat Pelaksana Dalam Melaksanakan Asuhan Keperawatan Di Ruang Rawat Inap RSUD Pasaman Barat Tahun 2010, Padang, Andalas University, 2010.

3. Berland A., Natvig G. K., Gundersen D., Patient safety and job-related stress: a focus group study, Intensive \& Critical Care Nursing, vol/no: 24(2), pp. 90-7, 2008.

4. Ford S., Stress at work makes nurses ill, Nursing Times, pp. 2-3, 2014.

5. Denison H., Dodds R., Ntani G., Cooper R., Cooper C., Sayer A., et al., How to get started with a systematic review in epidemiology: an introductory guide for early career researchers, Arch Public Health, vol/no: 71(1), pp.1-8, 2013.

6. Kitchenham B., Procedures for performing systematic reviews, Keele, UK, Keele University, vol/no: 33(2004), pp. 1-26, 2004.

7. Welch V., Petticrew M., Tugwell P., Moher D., Waters E., White H. W., et al., PRISMAEquity 2012 Extension: Reporting Guidelines for Systematic Reviews with a Focus on Health Equity, PLoS Medicine, vol/no: 9(10), pp. e1001333, 2012.

8. Cleophas T., Zwinderman A., Non-Parametric Tests. Statistical Analysis of Clinical Data on a Pocket Calculator, Springer Netherlands, pp. 9-13, 2011.

9. Cleophas T., Zwinderman A., t-Tests. Statistical Analysis of Clinical Data on a Pocket Calculator, Springer Netherlands, pp. 5-8, 2011.

10. Pearlin L., McCall M., Occupational Stress and Marital Support, In: Eckenrode J, Gore S, editors. Stress Between Work and Family, The Springer Series on Stress and Coping, Springer US, pp. 39-60, 1990.

11. Al-Makhaita H. M., Sabra A. A., Hafez A. S., Predictors of work-related stress among nurses working in primary and secondary health care levels in Dammam, Eastern Saudi Arabia, Journal of Family \& Community Medicine, vol/no: 21(2), pp. 79-84, 2014.

12. Yoon S. L., Kim J. H., Job-Related Stress, Emotional Labor, and Depressive Symptoms Among Korean Nurses, Journal of Nursing Scholarship, vol/no: 45(2), pp. 169-76, 2013.

13. Putra B. S., Analisis Faktor - Faktor Penyebab Stress Kerja Pada Perawat Pelaksana RS Tubu Ibu Cimanggis Tahun 2013, Depok, University of Indonesia, 2013.

14. Early E., Faktor - Faktor yang Menimbulkan Stress Kerja pada Perawat Pelaksana di Ruang Rawat Inap RS Husada Jakarta, Depok, University of Indonesia, 2003.

15. Lelyana M., Faktor - Faktor yang Berhubungan dengan Stres Kerja pada Perawat di RS PELNI 'Petamburan' Jakarta 2004, Depok, University of Indonesia, 2004.

16. Gautama D., Studi Stres Kerja Perawat di RS X, Depok, University of Indonesia, 2008.

17. Bhatia N., Kishore J., Anand T., Jiloha R. C., Occupational Stress Amongst Nurses from Two Tertiary Care Hospitals in Delhi, Australasian Medical Journal, vol/no: 3(12), pp. 7318, 2010.

18. Yu-Qin G., Bo-Chen P., Wei S., Hui W., Jia-Na W., Lie W., Anxiety symptoms among Chinese nurses and the associated factors: a cross sectional study, BMC Psychiatry, $\mathrm{vol} / \mathrm{no}:$ 12(1), pp. 141-9, 2012.

19. Wu H., Chi T., Chen L., Wang L., Jin Y., Occupational stress among hospital nurses: crosssectional survey, Journal of Advanced Nursing, vol/no: 66(3), pp. 627-34, 2010.

20. Karchani M., Barkhordari A., Pornajaf A., Raei M., Asaadi Z., Khobi J., et al., Job Stress and related factors in Nurses in Ilam, Electronic Physician, vol. 4, pp. 465-9, 2012.

21. Sharma P., Davey A., Davey S., Shukla A., Shrivastava K., Bansal R., Occupational stress among staff nurses: Controlling the risk to health, Indian Journal of Occupational and Environmental Medicine, vol/no: 18(2), pp. 52-6, 2014.

22. Rosch PJMDF, Special Edition: Exclusive Interview with Lennart Levi MD, PhD on Occupational Stress, Health and Stress, pp. 1-21, 2012. 
23. Sari I. P., Faktor - Faktor yang Berhubungan dengan Stres Kerja pada Perawat RS Jiwa DR Soeharto Heerdjan Tahun 2013, Depok, University Of Indonesia, 2013.

24. Utomo A., Gambaran Kejadian Stres Kerja Berdasarkan Kakteristik Pekerjaan pada Perawat Intensive Care Unit dan Unit Gawat Darurat di Rumah Sakit Mitra Keluarga Bekasi Tahun 2004, Depok, University of Indonesia, 2004.

25. Simanjuntak M., Faktor Risiko Stres Kerja pada Perawat Ruang Rawat Inap di RS Pantai Indah Kapuk Jakarta, Depok, University of Indonesia, 2013.

26. Lunau T., Siegrist J., Dragano N., Wahrendorf M., The Association between Education and Work Stress: Does the Policy Context Matter?, PLoS ONE, vol/no: 10(3), pp. 1-17, 2015.

27. Gobel R. S., Faktor - Faktor yang Berhubungan dengan Stress Kerja pada Perawat di Ruang ICU dan UGD RS Datoe Binangkang Kabupaten Bolaang Mongondow, Manado, Sam Ratulangi of University, 2014.

28. Cho J. J., Kim J. Y., Chang S. J., Fiedler N., Koh S. B., Crabtree B. F., et al., Occupational stress and depression in Korean employees, International Archives Of Occupational And Environmental Health, vol/no: 82(1), pp. 47-57, 2008.

29. Waldron, Occupational Health Practice, ButterworthsGreat Britain, 1989.

30. Sonmez B., Yildirim A., What are the career planning and development practices for nurses in hospitals? Is there a difference between private and public hospitals?, Journal of Clinical Nursing, vol/no: 18(24), pp. 3461-71, 2009. 